\title{
Practice Of License To Open State Land In Balikpapan
}

\author{
Deasy Ratna Sari \\ Faculty of Law, Hasanuddin University \\ Jln. Perintis Kemerdekaan Km. 12, Makassar, Sulawesi Selatan, Indonesia. \\ E-mail: sariratnadeasy@yahoo.com. \\ Abrar Saleng \\ Faculty of Law, Hasanuddin University \\ Jln. Perintis Kemerdekaan Km. 12, Makassar, Sulawesi Selatan, Indonesia. \\ E-mail:abrarsaleng@yahoo.com \\ Sri Susyanti Nur \\ Faculty of Law, Hasanuddin University \\ Jln. Perintis Kemerdekaan Km. 12, Makassar, Sulawesi Selatan, Indonesia. \\ Email : srisusyanti23@gmail.com
}

\begin{abstract}
This study aims to find out why the License to Open State Land can be the basis for land registration and to know the legal consequences on the sale and purchase of land objects based on the License to Open State Land. This research is done empirically juridically, that is by collecting data by researching and examining facts that exist in line with the observation in the field. Land issues in Indonesia are the responsibility of all parties involved, including the responsibilities of the central and local governments. The Local Government of Balikpapan City stipulates the IMTN regulation. The result of this research is the regional regulation aims to prevent and reduce the existence of land disputes by the orderly administration of land affairs. Land Acquisition License Can Become the Foundation for Laand Land Registration because it is legally determined that the license holder can apply for a right to land within 3 years since the IMTN is issued. As a result of the Law on Sale and Purchase of Land Objects Based on the License to Open the Land of the State ie the agreement becomes null and void and the sale and purchase agreement is considered never existed.
\end{abstract}

Keywords: License to Open Land State; Local Regulation; Land Registration

\section{INTRODUCTION}

Land is an important factor in men's life. Many things in men's life depend on land, likes on the land they builds a house to live in. ${ }^{1}$ On the land they can produce food because of the land they use for farming and gardening. Constitution of the Unitary state ofthe Republic of Indonesia 1945 is the main basis for the nation and government of the Republic of Indonesia in conduct the state activities. One of many written consensus that conclude in constitution is the affirmation of rule of law concept. ${ }^{2}$

Law Number 5 Year 1960, mostly known as the UUPA is one of the most have

\footnotetext{
${ }^{1}$ Boedi Harsono, (2005) ,Hukum Agraria Indonesia: Sejarah Pembentukan Undang-Undang Pokok Agraria, Isi dan Pelaksanaannya, Djambatan, Jakarta, page .5.

${ }^{2}$ Ahmad Hambali. (2015). Penyelesaian Penyelenggaraan Berat HAM Masa Lalu sebagai Pelaksana Pasal 281 ayat (2) UUD NRI Tahun 1945.Hasanuddin Law Review, 1(2): 266.
} 
"nationalism spirit" law, which mandate the state to create justice in control, utilization and management and ownership of resources through land reform programme. ${ }^{3}$ As a implementing regulation of UUPA, the government issued the Government Regulation Number 24 Year 1997 on Land Registration. ${ }^{4}$ Article 1 paragraph 1 mention that land registration is a series of activities that conducted by the government continuosly and regularly comprises of collecting, processing, bookkeeping, and presenting and maintaining physical and juridical data, in the form of maps and lists, of the plots of land and apartment units, including the submission of a certificate of land right property rights over apartment units as well as certain rights that burden it. ${ }^{5}$

Words of "state law" consist of "law" and"state" terms. ${ }^{6}$ In govern its definitions, every scholars could have stressing whether on "law"or "state" terms. All this time, understood that "state law" definitions have a categorical unsure such as supremacy of law, equality before the law, fair justice process, respect for human rights, etc. ${ }^{7}$

Since Law Number 32 Year 2004 on Local Government entry into forced, the law put the Province as a dual system. On the one side, Province put as a autonomy region that perform decentralization. And in the other side, the province is a central government "prolongation" that perform deconcentration in the province region. ${ }^{8}$ Licence to open land state (licence) is a based untuk registered the previous rights to the National Land Body to elevate the status in order to acquire the land rights. Licence to open land state actually is not a evidence tools of the rights but only a basis of the rights. Licence to open land state is a permit that given by the major or appointed official to a person or legal body to open or acces the advantage on the land that owned by state. The permit is the only basis for the persons and legal body to acquire the rights.

As regulated in article 10 paragraph (2) Local Government Regulation ${ }^{9}$ on Licence to open land state that "any rights holder responsible to filed the licence to open land state request before apply for the land rights". Those article showed that any existed rights basis such as Segel(seals) which is known in Balikpapan Regency as the basis rights required to

\footnotetext{
${ }^{3}$ Musakkir.(2013). Penyelesaian Sengketa Pertanahan Secara Berkeadilan. Jurnal Ilmu Hukum Amanna Gappa, 21(1) page 30.

${ }^{4}$ H. Ali AchmadChomzah, 2004,Hukum Agraria (Pertanahan Indonesia), Prestasi Pustaka, Jakarta, p.2.

${ }^{5}$ Ibid

${ }^{6}$ Purbacaraka, (2010), Perihal Kaedah Hukum, Citra Aditya, Bandung, p. 37.

${ }^{7}$ Hamdan Zoelva. (2015). Prospek Negara Hukum Indonesia: Gagasan dan Realita. Hasanuddin Law Review, 1(2): p. 179.

${ }^{8}$ Aswiwin Sirua. (2010). Kedudukan Ganda (Dual Position) Gubernur Sebagai Kepala Daerah dan Wakil Pemerintah (Pusat).Jurnal Ilmu Hukum Amanna Gappa, 18(3) p. 311.

${ }^{9}$ Local Government Regulation of Balikpapan Regency Number 1 Year 2014 on License to Open Land State.
} 
have the licence prior to filed the land rights request.

The procedure to acquire the licence needs about 3 months to wait for an objection or refutation that can be proposed if there is a legal subject which feels the land belongs to him, if there is any objection, the Licencecan not be issued. So, the evidence of ownership is only a seal of land and can not be upgraded to a land certificate, this can prevent a person to get a certificate of his land but if no objections then the proof of ownership of a person on a land is a letter of the licence.

Article 11 paragraph (1) of the Local Regulation of Balikpapan Regency Number 1 Year 2014 stipulates that "License holders may apply for a land rights within 3 (three) years from the date of the license is issued". Paragraph (2) "In the event, the application for acquire land rights can not be done within the period referred to in paragraph (1), the IMTN holders shall apply for an extension of permit as referred to in Article 9 paragraph (2)". ${ }^{10}$ Most of the license holders in event of transfer the land rights to other parties even though the certificate of land rights is in the process of issuing the certificate by the Land Office of Balikpapan City. So, it will causing some of legal problem.

Article 12 paragprah (1) Local Regulation, determined that state owned land which controlled by the people or legal entitiy with licence could not be : a. Transferred to the others party, or b. To be pledged as a collateral of a debt.In fact, many of Balikpapan City residents are conducting the sale and purchase of land based on the licence and many are also found on bulletin boards around the land that will be sold and by online trading sites the rights is based on the licence. Based on the background that has been mentioned above, the authors are interested to conduct further research in a thesis entitled of Practice of License to Open State Land in the City of Balikpapan.

\section{METHOD}

This research is conducted by empirically juridical, that is by collecting data by researching and examining facts that exist in line with field observation and then examined based on the relevant legislation to solve the problem. The type of data used in this study are primary and secondary data. In the data collection used several research instruments, including Interviews, Documentation and Observation. The overall data obtained from this research, both primary and secondary data will be processed and analyzed qualitatively. The library data analyzed by documentation teechnique is reviewing all of references and

\footnotetext{
${ }^{10}$ Article 9 paragraph (2) to acquire the extention of the licence as regulated in paragraph (1), the licence holders mustapply for the permit maximum thirty days berfore the expiry of the licence.
} 
regulations which had relevance to the problem. ${ }^{11}$ The method of thinking used in analyzing the collected data is by using the deductive method.

\section{ANALYSIS AND DISCUSSION}

\section{Implementation of License to Open State Land As the Basis of Land Registration}

Before we discussed further on the process of land registration for an acquire of land rights that has legal certainty, researchers will quote Hans Kelsen. According to Hans Kelsen, law is a system of norms. Norm is a statement that emphasizes the "should" or das sollen aspect by including some rules about what to do. Norms are deliberative products and human actions. Laws that contain general rules serve as guidelines for individuals behaved in a society, both in relation to their fellow individuals and in relation to society. ${ }^{12}$ These rules become the limits for the community in the burden or take action against individu. The existenc of such rules and the implementation of these rules raising the legal certainty. ${ }^{13}$ According to Gustav Radbruch, the law must contain 3 (three) identity values, namely as follows:

1. The principle of legal certainty (rechmatigheid), this principle reviewed from the juridical point.

2. The principle of legal justice (gerectigheit), This principle looks from a philosophical point of view, where justice is a common rights for everyone before the court.

3. The principle of legal benefit (zwechmatigheid) or doelmatigheid or utility.

Article 9 of Balikpapan City Regulation Number 1 Year 2014 on Licence the Open the Land State (IMTN), regulates that IMTN is valid for 3 (three) years since the signing of the license and may be extended 1 (one) time, so totally the validity is for 6 (six) years. However, if the license holders have not registered license for apply of land rights to the National Land Agency (BPN) of Balikpapan Regency, the license holder must re-apply for the license issuance. Those Arrangements intended for the citizens may immediately register the license to the office of National Land Agency (Badan Pertanahan Nasional/BPN) for the issuance of certificate.

\footnotetext{
${ }^{11}$ Erlis Septiana Nurbani,(2017) Perkembangan Teknologi Senjata dan Prinsip Proporsionalitas, Jurnal Ius (Kajian Hukum dan Keadilan) Volume 5 (1), p. 24-29

${ }^{12}$ Ahmad Yani, (2013), Pembentukan Peraturan Perundang-undangan yang Responsif (Catatan Atas UndangUndang No.12 Tahun 2011 tentang Pembentukan Peraturan Perundang-Undangan), Konstitusi Pers., Jakarta. P. 10

${ }^{13}$ Peter Mahmud Marzuki,(2008) Pengantar Ilmu Hukum, Kencana, p.58
} 
License based land registration applies only to the registration of land rights for the first time after the issuance of Local Regulation on IMTN. But for the citizens which have registered land titles based on seals that have been in the hands of BPN (National Land Agency) not obliged to re-register the land for the license issuance, as well as the citizens who have obtained certificates also no longer need to register their land to license. This regulation applies only to land that have not been registered with certificates after the issuance of license regulations.

The ongoing process of license application may be terminated if someone objected. If the license has been issued but there is someone is objected on the process, such a person must register the rebuttal to the PTUN for the cancellation of IMTN and also to the district court for his civil claim. This is similar to a refutation to the certificate holder.

\section{Legal Implication of Sale and Purchase of Land Objects under the License to Open State Land And The Responsibilites Of The Seller}

Generally, Sale and Purchase is governed in Article 1457 of the Indonesia Civil Code. The sale and purchase agreement is an agreement which one party binds himself to deliver an object and anothers to pay the agreed price. Sale and prchase activity is one of the agreement, it is necessary to consider the terms of the validity of the agreement. As provided in Article 1320 of the Indonesia Civil Code which provides that, the terms of the validity of a treaty are:

1. Agreement of the parties

2. The parties' competence

3. A certain thing

4. A lawful cause

Agreement means that there is conformity of the will of the parties, so that in making an agreement there should be no coercion, wickedness and fraud (dwang, dwaling, bedrog). Legal competence as one of the conditions of the validity of the agreement means that the parties to the agreement must an adult that has been aged 18 years or has been married, mentally healthy and permitted by law. If an immature person wishes to enter into an agreement, it may be represented by his/her parent or guardian while the mentally handicapped person may be represented by the attorney or the curator. 
In a contract the object of the agreement must be clear and determined by the parties, the object of the agreement may be in the form of goods or services, but can also be nothing to do. This particular thing in the contract is called achievement that can be material, skill or energy, and do nothing. ${ }^{14}$ To determine the goods that are the object of the agreement, can be used various ways such as: counting, weighing, or measuring. In the meantime, to determine services, it must be determined what one party should do. To determine about a particular matter as not to do something must also be explained in the contract. ${ }^{15}$ The term of halal is not the opposite of the word forbidden (haram) in Islamic law, but what is meant by halal is that the contents of the contract are not contrary to the laws and regulations.

Sale and purchase of Land Objects based on the License actually has been explicitly regulated in Licence to Open Land State of Balikpapan City's Local Regulation in Article 12 paragraph (1) that is "Land with state land status which controlled by individual or legal entity with IMTN license can not be transferred to other party or collateralized as a guarantee of a debt". But because of th lack of understanding of the people of Balikpapan City about the consequences that arise after the sale and purchase of IMTN's licene can harm the parties which involved in sale and purchases.

Based on the provisions of Article 12 above, the sale and purchase actions conducted based on the IMTN letter are clearly prohibited to be performed. This is contrary to the provisions of Article 1320 of the Indonesian Civil Code regarding the lawful terms of the treaty, especially the halal cause. Any cause is prohibited, if it is prohibited by law or against to the public morality or violated public order as provided in Article 1337 of Indonesia Civil Code. A lawful cause referred to in that article includes such conduct shall not be contrary to the laws and regulations which in this case have been clearly defined regarding the prohibition of IMTN letters to be transferred or sold. The non-fulfillment of the terms of a lawful cause makes the agreement null and void and the sale and purchase agreement was never considered.

\section{CONCLUSION}

From the description discussed above, researchers can conclude that the IMTN license holder must immediately register to obtain the Land Rights because of the time period of IMTN is only 3 (three) years since the IMTN is issued. Land registration based on IMTN

\footnotetext{
${ }^{14}$ Ahmdi Miru, (2013), Hukum Kontrak dan Perancangan Kontrak, Jakarta: Rajawali Pers, p. 30 ${ }^{15} \mathrm{Ibid}$
} 
applies only to registration of land rights for the first time after the issuance of the Local Regulation on the IMTN. But for people who have registered land titles based on seals that have been dealt with National Land Agency (BPN) no need to re-register the land for the issuance of IMTN.

The community to not only control the land physically but also must be able to prove the land rights with the juridical data and the chronological data. Control over the land in such manner will realized the community of how important the evidence of land that can give them strength position and legal certainty to the land they owned.

\section{BIBLIOGRAPHY}

\section{Books}

Ahmad Hambali. (2015). Penyelesaian Penyelenggaraan Berat HAM Masa Lalu sebagai Pelaksana Pasal 281 ayat (2) UUD NRI Tahun 1945. Hasanuddin Law Review, 1(2): 266.

Ahmad Yani, (2013), Pembentukan Peraturan Perundang-undangan yang Responsif (Catatan Atas Undang-Undang No.12 Tahun 2011 tentang Pembentukan Peraturan Perundang-Undangan), Konstitusi Pers., Jakarta.

Ahmadi Mirudan Saka Pati, (2008), Hukum Perikatan, PT. Raja Grafindo Persada, Jakarta

Ahmadi Miru, (2013), Hukum Kontrak dan Perancangan Kontrak, Rajawali Pers, Jakarta

Ali Achmad Chomzah, (2002), Hukum Pertanahan: Seri Hukum Pertanahan I \& II, Prestasi Pustaka, Jakarta.

Aswiwin Sirua. (2010). Kedudukan Ganda (Dual Position) Gubernur Sebagai Kepala Daerah dan Wakil Pemerintah (Pusat). Jurnal Ilmu Hukum Amanna Gappa, Volume 18(3)

Boedi Harsono, (2005), Hukum Agraria Indonesia: Sejarah Pembentukan Undang-Undang Pokok Agraria, Isi dan Pelaksanaannya, Djambatan, Jakarta

Erlis Septiana Nurbani, (2017), Perkembangan Teknologi Senjata dan Prinsip Proporsionalitas, JurnalIus (Kajian Hukum dan Keadilan) Volume 5 (1)

Hamdan Zoelva,(2015), Prospek Negara Hukum Indonesia: Gagasan dan Realita. Hasanuddin Law Review, Volume 1(2)

Maria Farida, ( 2007), Ilmu Perundang-undangan Jilid 1. PT Kanisius. Yogyakarta. 
Musakkir, (2013), Penyelesaian Sengketa Pertanahan Secara Berkeadilan. Jurnal Ilmu Hukum Amanna Gappa, Volume 21(1)

Peter Mahmud Marzuki, (2008), Pengantar Ilmu Hukum, Kencana

Pusat Bahasa Departemen Pendidikan Nasional, (2008),Kamus Besar Bahasa Indonesia, Pusat Bahasa, Jakarta.

Purbacaraka, (2010), Perihal Kaedah Hukum, Citra Aditya, Bandung. 